\title{
Should we trust banks when they sit on the board of directors?
}

\begin{abstract}
When financial markets are not fully developed large shareholders are an important feature of an efficient corporate governance system. Thanks to their (relative) financial strength, banks are good candidates to perform this leading role in the governance of firms. However, in the type of monitoring provided and in the strategies that they may choose, banks are affected by significant conflicts of interests: expecially when they exert power through proxy votes and they are important lenders of the firm.
\end{abstract}

Francesco Giavazzi is professor of economics at Bocconi University in Milan, a co-director of CEPR's International Macroeconomics Programme and a Research Associate of the National Bureau of Economic Research in Cambridge.

From 1992 to 1994 he served as director general of the Italian Treasury, where he was responsible for the management of the public debt and for privatizations. Since 1992 he has been member of the board and executive committee of I.N.A. spa, Italy's largest life insurance company. He is an editor of the European Economic Review, the official journal of the European economic association, and has written extensively of European monetary issues. His joint book with professor Alberto Giovannini Limiting Exchange Rate Flexibility: the European Monetary System, was published by MIT Press in 1990.

Marco Battaglini is Ph.D candidate at Northwestern University . In 1997 he received the 'Arturo Osio, Imbriani Longo, Guido Carli' fellowship from Banca Nazionale del Lavoro. 


\title{
Should we trust banks when they sit on the board of directors?
}

\author{
Francesco Giavazzi ANd MARCo BATtAgLini
}

\section{A 'I WEAR THE MORGAN COLLAR, BUT I AM PROUD OF IT'}

In the twenties, when the president of New York, New Haven and Hartford Railroad Charles Mellen said he was proud of his 'Morgan Collar', his company was only one of the many controlled by investment banks such as the House of Morgan. As J. Bredford De Long (1991) reports, in 1910-1920 these institutions were influential in corporations that capitalized nearly one and a half years' national product: the companies where the partners of J.P. Morgan and Company sat on the board of directors alone amounted to 30 per cent of the listed equity value. Banks such as the National City Bank, Kidder, Peabody and Company, Kuhn, Loeb and Company, First National Bank and J.P. Morgan and Company were quite different from today's US commercial banks. Until the Glass Steagal Act, these large investors played a very active role in industrial organization and development: monitoring the firms in which they sat, but also fostering and financing mergers or acquisitions ${ }^{2}$. In this sense, their activity was similar to that of the German Grossbanken ${ }^{3}$ which were, in the early years of the century, the channel through which German industrialization was financed.

The German and American historic experiences seem to be direct evidence in favour of financial systems where large financial investors like banks have a relevant role in firms' governance: both these countries in that period not only had double digit growth rates but also build up the basis of their industrial strength. However whether the beginning of the century in the USA was a golden era and the German financial system is an advisable option are still open questions.

When financial markets are not fully developed, large shareholders are an important feature of an efficient corporate governance system. Thanks to their (relative) financial strength, banks are good candidates to perform this leading role in the governance of firms. This is what happened in the examples cited above and what still happens today in Germany: where, for example, Deutsche Bank A.G. owns 28.5 per cent of the Daimler Benz A.G ${ }^{4}$. However, in the type of monitoring provided and in the strategies that they may choose, banks are affected by significant conflicts of interests: especially when they exert power through proxy votes and they are important lenders of the firm.

The question of the role of banks in corporate governance is particularly topical, because many countries have still to choose the corporate governance system. This is obviously true 
for the former socialist countries, where the collapse of the central states has left a real vacuum in the control of economic activity and asset stripping has become the norm. In Russia, as Aoki ${ }^{5}$ notes:

"...the director of a State owned enterprise, who had already built a virtually autonomous empire in the communist regime, became almost invincible after the dismantling of the party and its planning apparatus..."

Clearly, if these countries have to attract investments from foreign countries the vacuum should be filled by some sort of corporate control and banks may be a solution.

But it is also true for western countries - such as Italy - where (hopefully) privatizations will question the corporate governance status quo.

In this paper we examine the pros and cons of the presence of a bank on the board of directors of a firm. We will first study the activity of large shareholders in the governance of firms and then discuss whether banks can play this role. Since reality is much less clear-cut than theory, in order to draw some lessons for policy-makers, we 'test' the theoretical results trying to analyze and to interpret the cases of Japan and Italy.

\section{B OWNERSHIP STRUCTURES, LARGE SHAREHOLDERS AND THE EFFICIENT MANAGEMENT OF THE FIRM: WHAT DOES THEORY SAY?}

\section{Out of the 'black box': the benefits from the presence of a large shareholder}

Since the work by Berle and Means (1932) and Coase (1937), the traditional view of the firm as a profit maximizing entity has been questioned, and the emphasis has shifted to the contrasting interests of the different stakeholders. Economists have recognized that the hypothesis of profit maximization is somewhat arbitrary, and not necessarily supported by the empirical evidence: a more solid theory of the firm, founded on the study of the interaction among stakeholders, was thus needed. As Jensen and Mackling put it:

" The firm is not an individual. It is a legal fiction which serves as a focus for a complex process in which the conflicting objectives of individuals (some of whom may "represent" other organizations) are brought into equilibrium within a framework of contractual relations. In this sense the behavior of the firm is like the behavior of the market; i.e., the outcome of a complex equilibrium process. "

With respect to this view, the distribution of ownership rights seemed a crucial element in order to understand what lies inside the 'black box'. In the thirties Berle and Means argued that due to the dispersion of ownership rights that characterizes the modern corporation, 
shareholders' control over managers is relaxed, and managers are free to pursue their own interests, which often are in contrast with those of the shareholders. Dispersed ownership rights have thus been associated with managerial discretion and with divergence from profit maximization. The work of Berle and Means started a long debate over the desirability of concentrated ownership structures as a solution to many corporate governance problems.

An assessment of the pros and cons of concentrated ownership structures - i.e. of the presence of a large shareholder - needs, however, an analysis of a wide range of variables that influence the performance of corporations. To understand the role played by a large shareholder (LSH) it is necessary to distinguish two cases: a) when the LSH directly manages the firm (inside shareholder); b) when, on the contrary, the LSH is an outsider: he does not manage the firm directly, and does not enjoy private benefits of control (see Figure 1). In the first case there is an obvious advantage from the presence of an insider-manager with a large stake in the firm: the alignment of interests between insiders and outsiders that derives from it. When an insider owns 100 per cent of the firm he fully enjoys all the benefits that derive from his efforts: he would enjoy 100 per cent of any increase in profits and in firm value. On the contrary, if the insider-manager owns, say, 30 per cent of the firm he would enjoy only 30 per cent of the increase in profits that would follow from higher personal effort in the management of the firm: he would, however, bear the full costs of this increased level of effort. Therefore, the lower is the fraction of the firm owned by insiders-managers, the lower are the marginal benefits that the insider enjoys from an improved management. When the stake of insiders-managers is negligible we are back to the case described by Berle and Means: the interests of insiders may differ considerably from those of shareholders.

In the second case, the role of a large shareholder who is not an insider is much less intuitive since outsiders do not manage the firm directly: however, this case is important because typically, and not only in the US ${ }^{7}$, managers own small fractions of a firm's capital. The relevance of the presence of an outside LSH is indirect: it may foster (or hinder as we shall see in the next paragraph) the disciplinary devices that limit managerial discretion, such as take-overs and internal monitoring by outside shareholders. In general, any disciplinary device suffers from a free-rider problem. The efficient management of firms is a public good: a small shareholder who wanted to increase his monitoring effort would bear the full cost of this activity, but would gain only a fraction of the benefit. Improvements in firm management are reflected in higher profits; however, a small shareholder would receive only the small fraction that is proportional to his share of ownership rights - and co-ordination of small shareholders in order to redistribute the costs of a managerial improvement would be prohibitively expensive since a very large number of shareholders would have to be involved. 
FIGURE 1

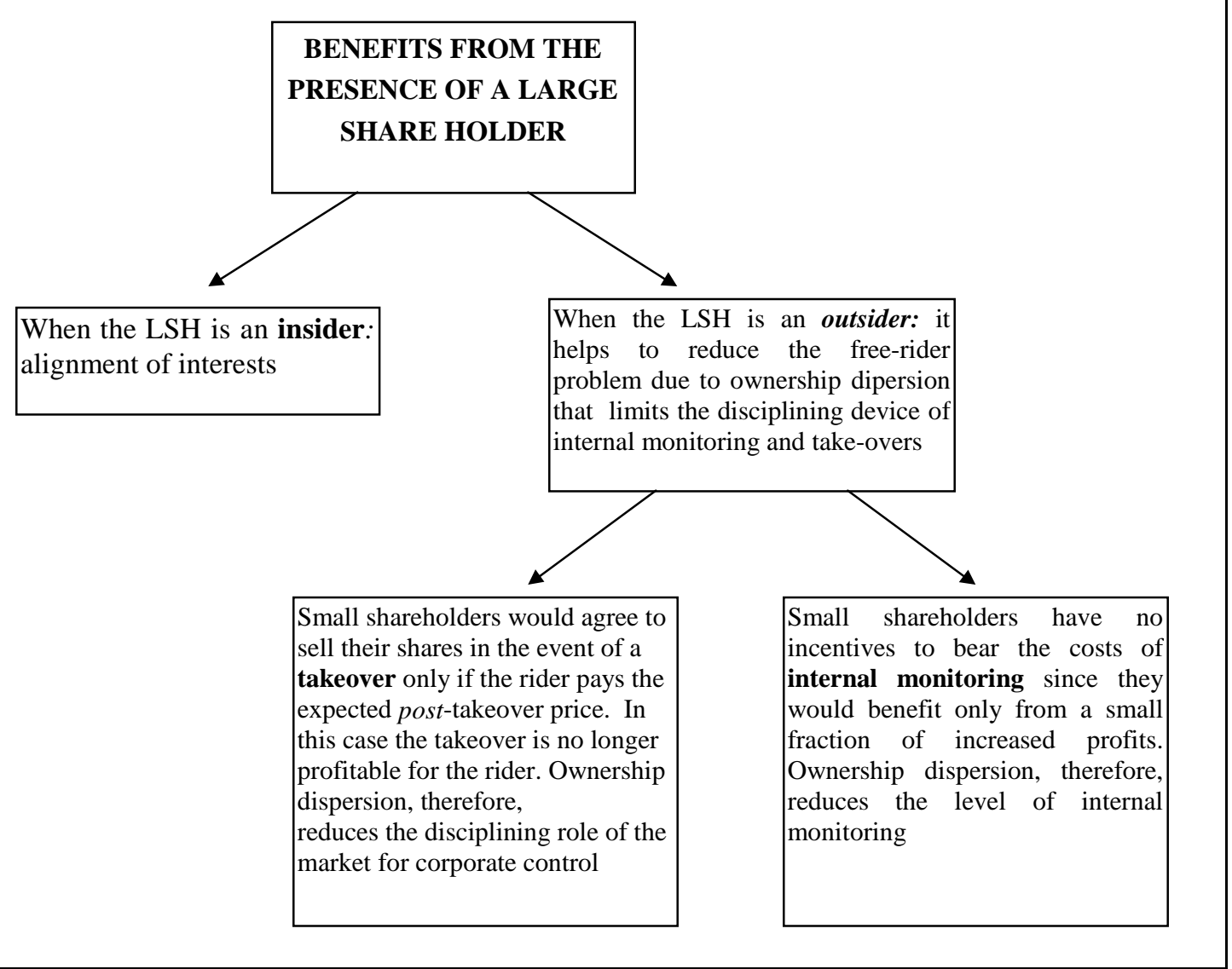

It is useful to make a distinction between the types of free-rider problem that may arise as the results differ from one case to the other and, in particular, a different role for the LSH emerges in the two cases. A first type of free-rider problem arises when takeovers are the relevant disciplinary device. As argued by Grossman and Hart (1980), any profit a raider can make from the increase in share price after a takeover, it is a profit that other outside shareholders could have made had they not tendered their shares to the raider. If an outsider holds very few shares and, therefore, thinks that, even if he does not tender, the take-over will be successful, his rational choice would be to wait and sell after the expected improvement, or to sell at a price equal to the expected post-takeover value. But in this case the raider would not have enough incentives to launch the takeover. Yet, Shleifer and Vishny (1986) point out that a large shareholder would still benefit from launching a takeover. Suppose he owns 49 per cent of the firm and needs 51 per cent to seize control: in this case he would need to buy only 2 per cent of the firm and, even if he paid the full post-takeover value, he would enjoy the increase in value over the 49 per cent. However, a shareholder who owned only 2 per cent would need to buy 49 per cent of the firm and would therefore profit only over his initial tiny stake. 
A different type of free-rider problem arises when "Barbarians are not at the gate" and the only disciplinary device is direct monitoring of outside shareholders over managers. In many legal systems even small shareholders can sue managers who breach their fiduciary duty: it could thus be argued that ownership concentration is no longer relevant. However, a free-rider problem is present here too: since monitoring is a public good, small shareholders would try to enjoy other shareholders' monitoring, thus producing a sub-optimal level of control. Obviously, the presence of a LSH overcomes this inefficiency, since a LSH internalizes enough benefits to bear the costs of monitoring.

This distinction is not only academic: on the contrary, it is very useful to interpret different corporate governance structures. In particular the 'function' that a large shareholder performs is in these two situations - monitoring through the threat of takeovers, as opposed to direct monitoring - is very different, and suggests that the characteristics of a large shareholder that could improve corporate governance depend on the features of the financial system, and will therefore differ from country to country.

In the presence of an active market for corporate control, the large shareholder does not need to belong to a board of directors that performs a day-to-day monitoring activity: discipline is exercised through the threat of a takeover. In particular, as Shleifer and Vishny (1986) demonstrate, there are situations in which the LSH should undertake not to talk to the incumbent management. The reasonong runs as follows: large improvements in firm value require a change of the incumbent management through a takeover; only smaller improvements could be realized at a lower cost with informal negotiations ('jawboning'). Hence, when the large shareholder decides to launch a takeover, the other shareholders interpret this as a signal that there will be a large improvement in the value of the firm: thus they tender only for large premia. For these reasons, the LSH may be worse off with the option to jawbone: if he undertakes not to negotiate with the incumbent management, in the case of a takeover he would face smaller expected premia and, thus, higher expected profits.

On the contrary, when the market for corporate control is dormant, and only internal monitoring can affect managers' behaviour, the role of a LSH is considerably different: he is directly involved in day-to-day monitoring and is an active member of the board of directors. Casual evidence seems to confirm this distinction. In Germany, where take-overs are not frequent, large shareholders take an active part in the Aufsichtsrat, the firm's supervisory board, and control managers directly: this function is normally performed by non financial institutions and by banks - since mutual funds in Germany are not much developed. In the Anglo-Saxon financial systems, on the other hand, where the typical LSH is a mutual fund or a pension fund, these investors play a much more passive role, but their role is often crucial in the event of a takeover ${ }^{8}$. 
It is often argued, in this respect, that continental European countries should actively develop institutional investors other than banks - such as mutual and pension funds - since their presence would improve corporate governance. However, since these types of large shareholders are not generally involved in day-to-day monitoring, and do not play an active role on the board of directors - often their statutes prevent them from sitting on the board of directors - they are probably not very useful (at least as far as corporate governance is concerned) in countries where an efficient market for corporate control does not exist and take-overs are rare.

Large shareholders are often associated with financial systems where takeovers are not frequent, as a substitute for market discipline (for example in Germany and Japan), while dispersed ownership is associated with an Anglo-Saxon type financial system. However, a scope for concentrated ownership is theoretically justified also in market-based financial systems. As reported by Shleifer and Vishny (1986), more than half of the Fortune 500 firms have at least one large shareholder holding a block of shares that exceeds 5 per cent of the firm's capital. The fact that ownership concentration is lower than in Germany is not only a consequence of economic incentives: it is also the result of a legal system that strongly discourages shareholders from being actively involved in control (see, for example, Prowse 1995) because of antitrust and fiscal regulations, and of stricter disclosure requirements.

\section{The flip-side of the coin: the costs of the presence of a large shareholder}

In the previous paragraph we stressed the benefits that can derive from the presence of a LSH: we now turn to the costs and inefficiencies that a concentrated ownership structure could generate. The empirical evidence suggest that there is a trade-off in the choice of the best ownership structure. In particular, it seems that the relationship between ownership concentration and the value of the firm is not monotone. Morck, Shleifer and Vishny (1988), for example, estimate the relation between Tobin's $q$ and the fraction of shares owned by insiders in a sample of 371 large US firms: ownership concentration seems to improve the ratio of firm market value to the replacement costs of its assets (Tobin's q) significantly only if the share owned by insiders is below 5 per cent; between 5 and 25 per cent the relationship is, on the contrary, negative; only a weakly positive relationship is found for concentration levels higher than 25 per cent. Similar results are found by other studies ${ }^{9}$. The study by Slovin and Sushka (1993) is noteworthy since it employs a different methodology, trying to solve the potential causality problem that affects other studies ${ }^{10}$. They analyze the impact on the firm's value of an exogenous event that affects the ownership structure of the firm: the death of a large inside blockholder. Here too the relation between the death of the insider (which causes ownership dispersion) and firm value does not seems to be monotone, and does not support the 'alignment of interest hypothesis', which would suggest the optimality of the presence of a 
large shareholder: they find that the response of the share price to the death of an inside blockholder is significantly positive when the share controlled by the deceased exceeds 10 per cent.

Theoretically, there could many reasons for the presence of a trade off in the choice of the optimal ownership concentration. First of all, and most obviously, the concentration of ownership rights limits the opportunities to diversify risk and, therefore, reduces the expected utility of risk-averse agents. However, what is most relevant for our discussion are the drawbacks that are directly related to the corporate governance of the firm: the undesired effects on managers' incentives. Here it is useful to return to the distinction between an insider and an outsider LSH.

In the first case we could have the so-called 'entrenchment effect': when insiders own a large fraction of equity, the probability that a hostile take-over succeeds is reduced, and the incumbent management is sheltered from outside discipline. ${ }^{11}$ In this case a LSH would be sheltered from the threat of a take-over and could thus try to exploit the private benefits of control. These could be so large that the LSH could be better off maximizing them rather than the value of the firm, even if he owns a large fraction of it. Private benefits can be of many types. A famous historical example is provided by the Italian Banca di Sconto in the first half of the century: the owners (the Perrone family) used the bank's funds to finance their own non-financial activities (Ansaldo, a manufacturing firm) leading the bank into bankruptcy. The trade-off here is between the 'alignment of interests hypothesis', which we discussed above, and the 'entrenchment effect'.

When the LSH is an outsider, the case is different, but there are drawbacks here too. Burkart, Gromb and Panunzi (1995) point out that the presence of a LSH could hinder managers' discretion and therefore depress their initiative. A large shareholder has the power to turn down the management's plans, thus limiting their discretion, authority and initiative: the outcome can be that managers have weaker incentives to 'work hard'. If managers' initiative is valuable, it may be optimal to limit monitoring, leaving them enough authority. A dispersed

ownership structure may work as a commitment device to delegate authority from shareholders to self-interested managers.

Hölmstrom and Tirole (1993) point to yet another trade-off. The presence of a LSH (who typically is a long term-investor) reduces the liquidity of the market (see also Bhushan, 1989): this reduction in liquidity limits the ability of speculators to disguise themselves as prices become more sensitive. Since speculators can use their information less effectively, they will have less incentives to monitor and gather information: the market thus becomes less informative, resulting in a less efficient allocation of resources. 
Table 1.

What theory suggests

\begin{tabular}{|c|c|c|}
\hline \multirow{2}{*}{$\begin{array}{c}\text { CHARACTERISTICS OF THE } \\
\text { FINANCIAL MARKET } \\
\end{array}$} & \multicolumn{2}{|c|}{ THE LARGE SHAREHOLDER IS AN } \\
\hline & INSIDER & OUTSIDER \\
\hline $\begin{array}{l}\text { TAKEOVERS ARE THE } \\
\text { NORM }\end{array}$ & $\begin{array}{l}\text { LSH profile: active investor who joins the } \\
\text { board of directors and manages the firm } \\
\text { directly. } \\
\text { Benefits: the interests of shareholders and of } \\
\text { managers are aligned. } \\
\text { Costs: 1) 'entrenchment effect' } \\
\text { 2) reduction in the } \\
\text { informational role of prices. }\end{array}$ & $\begin{array}{l}\text { LSH profile: passive investor who votes with } \\
\text { his feet and does not share managerial } \\
\text { responsibilities. } \\
\text { Benefits: higher discipline from the market for } \\
\text { corporate governance. } \\
\text { Costs: it reduces the informational role of prices. }\end{array}$ \\
\hline $\begin{array}{c}\text { TAKEOVERS ARE } \\
\text { RARE }\end{array}$ & $\begin{array}{l}\text { LSH profile: active investor who joins the } \\
\text { board of directors and manages the firm } \\
\text { directly. } \\
\text { Benefits: the interests of shareholders and of } \\
\text { managers are aligned. } \\
\text { Costs: the LSH could have no } \\
\text { counterbalance, and could thus maximize } \\
\text { private benefits, if these are high enough. }\end{array}$ & $\begin{array}{l}\text { LSH profile: active investor who joins the board } \\
\text { of directors and strictly controls management. } \\
\text { Benefits: more incentives to monitor since it } \\
\text { internalizes the benefits. } \\
\text { Costs: LSH tends to monitor too much, reducing } \\
\text { managers' incentives. }\end{array}$ \\
\hline
\end{tabular}

It follows that information plays very different roles in markets characterized by the presence of a LSH, compared with situations where ownership is dispersed. In the ShleiferVishny case we have 'strategic information': the large shareholder is interested in information about potential value under a new management and a new strategy. In the other case (the one analyzed by Hölmstrom and Tirole) we have the production of 'speculative information': there is no expected change in management and strategy, and speculators try to forecast the consequences of past managerial actions

The bottom line of this brief review of the literature is that there is a direct relation between the market for corporate control (its liquidity and efficiency), the allocation of voting rights, and the type of incentives and information that it is produced by the system in equilibrium. 


\section{Conclusions and further questions}

From our discussion so far it appears that the choice of an optimal concentration of ownership is not a trivial question. Table 1, which summarizes the main theoretical results, shows that at least two dimensions are relevant to assess the pros and cons of the presence of a large shareholder: 1) the degree of collusion between the LSH and the management; and 2) the context in which the LSH operates, whether or not the market for corporate control is efficient. It is quite meaningless to discuss the benefits of a LSH without simultaneous reference to these two features: a LSH-insider in an environment that does not allow for takeovers - and therefore for the correction of adverse-selection problems - could be very harmful in the absence of adequate large outside shareholders who act as watchdogs. On the contrary, when LSHs do not collude with management, they may effectively limit managers' moral hazards, both because they foster market discipline and, when markets are particularly under-developed, they may monitor the management directly.

In conclusion, two points should be remembered, and will be further analyzed in the pages that follow:

1) it is widely held that the presence of LSH is particularly beneficial in financial systems that are not fully developed. It is in fact argued that in countries with a developed market for corporate control take-overs may be sufficient to limit managerial discretion. However, a role for LSHs is present also in countries with efficient financial markets: where ownership dispersion creates a free-rider problem, a LSH can facilitate a take-over, thus strengthening market discipline;

2) it is important to study the incentives that the LSH has to monitor. The size of his stake is an important variable, but other elements should be considered. For example, the activity of the LSH: as we shall further explain below (whether it is a bank, a mutual fund, or a private non-financial investor) and therefore the other business relations that it may entertain with the firm.

\section{DOES IT MAKE A DIFFERENCE WHO IS THE LARGE SHAREHOLDER? THE ROLE OF BANKS}

In the previous paragraphs we argued that one of the main benefits from the presence of a LSH is the fact that it provides a monitoring activity over incumbent managers: because of a free-rider problem, only a LSH can enjoy sufficient benefits from monitoring to find it profitable to bear the cost. 
In making this point, we assumed that the goal of an outside LSH was simply the maximization of the value of its share of ownership rights. Although we already mentioned private benefits, we have not yet studied the possibility that a LSH, in its monitoring activity, may be subject to incentives and conflicts. LSHs, typically, are institutional investors - such as banks, pension funds or insurance companies - which often have important business relations with the firms in which they own large blocks of shares. Banks, for example, will want to sell loans; insurance companies and mutual funds manage pension plans, and so on. The monitoring activity performed by these types of shareholders will thus be influenced by their overall relations with the firm. Institutional ownership of common stock has substantially increased since the seventies. In the United States it increased from approximately 17 per cent in 1970, to more than 30 per cent in the mid-eighties. This calls for an analysis of how institutional voting power is exercised, and to what extent it depends on the other business relations that institutional investors entertain with the firm.

The available evidence points to well established patterns of behavior. Brickley, Lease and Smith (1988), in particular - who study the voting behavior of different classes of institutional investors - confirm this point. They divide investors in three groups: pressure-sensitive institutions, that is institutions with relevant business relations with the firm in which they have shareholdings, such as insurance companies, banks, and non-bank trusts owing at least one percent of the firm's stock; pressure-resistant institutions, such as public pension funds, endowments, and foundations; and institutions that they call pressure indeterminate, in particular mutual funds. They find that the stance toward the incumbent management is quite different for these classes of investors: pressure resistant institutions are more likely to oppose management, and that the hypothesis that pressure sensitive institutions and pressure resistant institutions have the same voting behavior can be statistically rejected. In this paragraph we shall describe the potential conflicts of interest that may interfere with the monitoring activity that a bank-LSH is supposed to perform..

Banks are, perhaps, the most relevant case to study: both because of the degree of the potential conflict of interest, and because of the important role that they play, as institutional investors, in continental Europe and in Japan. There may be significant conflicts of interests between of a bank as lender and as shareholder of a firm: banks may use their shareholdings to enforce their rights 'as lenders' rather than 'as shareholders'. In Germany and Japan, banks are, at the same time, important share-holders and debt-holders. As noted by Sheard (1989), in 
1980, the 'main bank' of a Japanese listed company - that is the bank which provides and guarantees most of the firm's debt finance - had the largest, or second-largest, shareholding in 39 per cent of the cases; in 72 per cent of cases it was among the first five shareholders (see Table 3.)

Prowse (1995), among the 133 Japanese firms that he analyses ${ }^{12}$, finds that in 57 cases the largest debt-holder is also the largest shareholder, and in 124 cases the largest shareholder and debt-holder are members of the same keiretsu.

The situation in Germany is similar. Even if the importance of bank finance - both through debt and equity - is less relevant what is generally believed ${ }^{13}$, German banks play a crucial role in the financing of industry: 20 per cent of gross finance for investment on average, between 1970 and $1985 .^{14}$

The fact that a bank is at the same time an equity holder and (the main) lender is important because a share-holder and a debt-holder have different and possibly contrasting incentives to monitor the firm. As debt-holder the bank is not interested in boosting firm profits: what matters for a lender is that profits are large enough to service the debt. The pay-off of a lender is concave in the pay-off of the firm: it could be very low if the firm goes bankrupt, but it is limited if profits are high. Therefore, the lender will tend to limit investments in projects with risky payoffs - because he would bear the risks but not the benefits. Monitoring by a lender focuses on the minimization of the probability of bankruptcy: there are no incentives for a lender to monitor a firm in good states of the world, since the benefits from this activity only accrue to shareholders. Clearly, this type of 'debt-driven' monitoring leads to socially inefficient outcomes; a lender will try to block projects with a relatively high probability to fail, but also with very high expected pay-offs: the bank's risk aversion will cause the loss of good investment opportunities, or produce a downward bias in $R \& D$ expenses.

When the bank also owns equity in the firm, this problem is alleviated, because the pay-off function becomes a weighted average of that of a debt-holder and that of an equityholder. However, the bias toward a sub-optimal risk configuration remains. Yet, in many cases, banks control voting rights without directly owning the underlying equity: thus, in taking decisions, only the incentives that derive from their provision of debt finance are relevant. This is certainly the case of Germany, where the proxy market is dominated by banks. As can be seen from Table 4, the voting power of German banks derives more from proxy votes than from direct shareholdings. For instance, in the ten largest AGs, in 1974, banks' combined votes amounted to 67.03 per cent of the total, but only 3.56 per cent was related to direct equity-holdings. 
TABLE 2

\section{WHO IS ‘THE BEST’ LSH?}

\begin{tabular}{|c|c|c|c|c|}
\hline & & $\begin{array}{l}\text { Do they have incentives to } \\
\text { own big blocks of shares? }\end{array}$ & Is there conflict of interests? & Who controls the controller? \\
\hline \multirow[t]{2}{*}{$\begin{array}{l}\text { MUTUAL } \\
\text { FUNDS }\end{array}$} & CLOSED- END & $\begin{array}{l}\text { Yes: closed-end funds are } \\
\text { used to finance venture } \\
\text { capital investments; but they } \\
\text { are not common in the US. }\end{array}$ & $\begin{array}{l}\text { No, since they generally have } \\
\text { no other business relations } \\
\text { with the firms in which they } \\
\text { invest their portfolio. }\end{array}$ & $\begin{array}{l}\text { Discipline over closed-end } \\
\text { mutual fund managers is not } \\
\text { as high as in the case of open- } \\
\text { end funds. However, a strict } \\
\text { regulation limits managerial } \\
\text { discretion. }\end{array}$ \\
\hline & OPEN-END & $\begin{array}{l}\text { No: they must be liquid since } \\
\text { they must be ready to turn } \\
\text { shares into cash to face } \\
\text { redemptions. In the US, } \\
\text { Section 16.b of the SEA } \\
\text { strongly discourages short- } \\
\text { term swing trading. }\end{array}$ & $\begin{array}{l}\text { No, since they generally have } \\
\text { no other business relations } \\
\text { with the firms in which they } \\
\text { invest their portfolio. }\end{array}$ & $\begin{array}{l}\text { There is a high level of } \\
\text { control. Liquid open-end funds } \\
\text { that redeem overnight provide } \\
\text { excellent discipline over fund } \\
\text { managers. }\end{array}$ \\
\hline \multicolumn{2}{|c|}{ BANKS } & $\begin{array}{l}\text { In countries where banks are } \\
\text { allowed to acquire blocks of } \\
\text { shares, they tend to do it. } \\
\text { See, for example, France } \\
\text { after the } 1984 \text { bank reform } \\
\text { act. }\end{array}$ & $\begin{array}{l}\text { Banks as lenders tend to be } \\
\text { more concerned with the } \\
\text { bottom part of the tail of the } \\
\text { distribution of returns. }\end{array}$ & $\begin{array}{l}\text { It depends on the ownership of } \\
\text { the bank. In Germany, banks } \\
\text { are manager-controlled. Even } \\
\text { if banks are subject to strict } \\
\text { prudential regulation, this does } \\
\text { not mean that banks are } \\
\text { necessarily good shareholders. } \\
\text { The regulator is concerned } \\
\text { with bank solvency, and not } \\
\text { with the role of the bank 'as } \\
\text { shareholder', making the bank } \\
\text { even more risk averse. }\end{array}$ \\
\hline \multirow[t]{2}{*}{$\begin{array}{l}\text { PENSION } \\
\text { FUNDS }\end{array}$} & $\begin{array}{c}\text { FIXED } \\
\text { PAYMENTS }\end{array}$ & $\begin{array}{l}\text { They tend to invest in more } \\
\text { liquid securities, and avoid } \\
\text { large blocks. }\end{array}$ & $\begin{array}{l}\text { At least in the US there is a } \\
\text { potentially large conflict of } \\
\text { interest since, in the private } \\
\text { sector, pension funds are } \\
\text { typically controlled by the } \\
\text { management of the firm. } \\
\text { Public pension funds act in a } \\
\text { much more independent way. }\end{array}$ & $\begin{array}{l}\text { Except in the case of public } \\
\text { pension funds, managers } \\
\text { control the pension fund of } \\
\text { their own firm. }\end{array}$ \\
\hline & $\begin{array}{c}\text { FIXED } \\
\text { CONTRIBUTION }\end{array}$ & $\begin{array}{l}\text { They could be assimilated to } \\
\text { mutual funds that are not } \\
\text { subject to overnight } \\
\text { redemptions; thus, they } \\
\text { could own large equity } \\
\text { blocks }\end{array}$ & $\begin{array}{l}\text { At least in the US there is a } \\
\text { potentially large conflict of } \\
\text { interest since, in the private } \\
\text { sector, pension funds are } \\
\text { typically controlled by the } \\
\text { management of the firm. } \\
\text { Public pension funds act in a } \\
\text { much more independent way. }\end{array}$ & $\begin{array}{l}\text { Except in the case of public } \\
\text { pension funds, managers } \\
\text { control the pension fund of } \\
\text { their own firm. This can be a } \\
\text { problem if the amount invested } \\
\text { in their own firm is small, } \\
\text { because casual evidence shows } \\
\text { that there may be collusion } \\
\text { between managers of different } \\
\text { firms. }\end{array}$ \\
\hline \multicolumn{2}{|c|}{ INSURANCE COMPANIES } & $\begin{array}{l}\text { Yes: since they can forecast } \\
\text { their capital outflows, they } \\
\text { do not suffer the overnight } \\
\text { redemption problem of open- } \\
\text { end mutual funds. }\end{array}$ & $\begin{array}{l}\text { Since they are large holders of } \\
\text { corporate bonds, like banks } \\
\text { they may be more interested in } \\
\text { the service of their debt rather } \\
\text { than in firm profitability. }\end{array}$ & $\begin{array}{l}\text { It depends on who owns the } \\
\text { insurance company. }\end{array}$ \\
\hline
\end{tabular}


TABLE 3

\begin{tabular}{|c|c|c|c|c|}
\hline \multicolumn{5}{|c|}{$\begin{array}{l}\text { LISTED JAPANESE FIRMS ACCORDING TO RANK OF MAIN BANK AS SHAREHOLDER IN 1980, } \\
\text { AND SOURCE OF BORROWING IN } 1971\end{array}$} \\
\hline & \multicolumn{4}{|c|}{ Breakdown of listed firms } \\
\hline & \multicolumn{2}{|c|}{$\begin{array}{l}\text { Rank of main bank as shareholder, } \\
1980\end{array}$} & \multicolumn{2}{|c|}{$\begin{array}{l}\text { Rank of main bank as debt holder, } \\
1971\end{array}$} \\
\hline Rank & $\begin{array}{l}\text { No. of } \\
\text { firms }\end{array}$ & $\begin{array}{l}\text { Relative } \\
\text { frequency }(\%)\end{array}$ & $\begin{array}{l}\text { No. of } \\
\text { firms }\end{array}$ & $\begin{array}{l}\text { Relative } \\
\text { frequency }(\%)\end{array}$ \\
\hline 1 & 124 & 16.4 & 469 & 67.3 \\
\hline 2 & 172 & 22.7 & 125 & 17.2 \\
\hline 3 & 113 & 14.9 & 47 & 6.5 \\
\hline 4 & 84 & 11.1 & 17 & 2.3 \\
\hline 5 & 52 & 6.9 & 14 & 1.9 \\
\hline 6 & 34 & 4.5 & 7 & 1.0 \\
\hline 7 & 20 & 2.6 & 10 & 1.4 \\
\hline 8 & 13 & 1.7 & 7 & 1.0 \\
\hline 9 & 15 & 2.0 & 2 & 0.3 \\
\hline 10 or more & 131 & 17.3 & 9 & 1.2 \\
\hline Total & 758 & 100 & 727 & 100 \\
\hline
\end{tabular}

The empirical literature has begun to study the monitoring activities of banks, investigating to what extent they depend on the incentives that derive from debt and equity holdings. Kaplan, in a series of related papers ${ }^{15}$, has studied the relation between management compensation and management turnover, and firm performance in German, Japanese and US companies. Since the relation between the rewards of managers and the performance of the firm reflects the objectives of the board of directors - and therefore those of the shareholders these findings provide evidence on the behavior and on the type of incentives that a bankbased corporate system and a market-based system exert on managers. Kaplan finds that in Japan and in Germany, like in the US, managers' turnover and compensation are positively correlated with the current performance of the firm, as measured by stock returns and earnings. However, in Japan and in Germany both compensations and turnover are more sensitive to negative earnings. In both countries governance mechanisms seem to become active when the firm faces difficulties in servicing the debt: this triggers the appointment of new executive directors, and a turn-over of management.

Kaplan and Minton (1993) further study the characteristics of the appointments of outside directors in Japan, trying to distinguish between bank appointments and appointments by non-financial firms. Although both types of outside appointments are disciplinary (in the sense that they are followed by a turnover of incumbent managers), they seem to depend upon 
different circumstances. Bank appointments are strongly correlated with the ratio of total debt to assets and, in particular, to the relative amount of borrowing from the largest lender: a two standard deviation difference ( 14 per cent) in this variable is accompanied by a 5 per cent increase in the likelihood of a board appointment. But what is particularly noteworthy is the fact that the likelihood of a bank-designated director being appointed to the board does not depend on the bank's shareholdings - thus suggesting that a bank appointment to the board is driven by its lending activity and not by its shareholdings. "These patterns provide additional support for the view that bank-designated directors are appointed in firms and situations where there is a bank loan to protect" ${ }^{16}$.

TABLE 4

BANK S’ VOTING RIGHTS IN 56 AMONG THE TOP 100 GERMAN AGs IN 1974

\begin{tabular}{|c|c|c|c|c|c|}
\hline $\begin{array}{l}\text { Rank class of AGs } \\
\text { by nominal capital }\end{array}$ & $\begin{array}{l}\text { Number of AGs } \\
\text { with combined } \\
\text { bank vote }>5 \%\end{array}$ & $\begin{array}{l}\text { Nominal capital of } \\
\text { AGs in column (2) } \\
\text { as percent of } \\
\text { nominal capital of } \\
\text { rank class }\end{array}$ & $\begin{array}{l}\text { Average } \\
\text { percentage of bank } \\
\text { vote in AGs in } \\
\text { column (2) due to } \\
\text { banks' direct } \\
\text { holdings of equity }\end{array}$ & $\begin{array}{l}\text { Average } \\
\text { percentage of bank } \\
\text { vote in AGs in } \\
\text { column (2) due to } \\
\text { proxy votes }\end{array}$ & $\begin{array}{l}\text { Average combined } \\
\text { bank vote in AGs } \\
\text { in column (2) }\end{array}$ \\
\hline $1-10$ & 8 & 88.2 & 3.56 & 63.47 & 67.03 \\
\hline $11-25$ & 6 & 42.5 & 6.10 & 48.19 & 54.29 \\
\hline $26-50$ & 14 & 51.3 & 14.65 & 25.03 & 39.68 \\
\hline $51-100$ & 28 & 54.4 & 13.52 & 29.01 & 42.53 \\
\hline
\end{tabular}

Source: Edwards and Fischer (1991). Data taken from Monopolkommission, II Hauptgutachten 1976/1977.

Additional evidence on bank behaviour is provided by Weinstein and Yafeh (1994), who study the effects of a bank-centered financial system (Japan, where, as we said, banks are at the same time large equity-holders and debt-holders) on firm performance. Firms with tight financial links with a bank seem to suffer less from credit rationing problems, especially when capital markets are underdeveloped. But the firm pays a cost for this provision of liquidity: the authors find that the 'main bank' extracts relevant rents from its position: the profitability of firms with strong bank relations is significantly lower than that of 'independent firms'; they also tend to grow slower.

An interpretation of these findings could be that the main bank puts its interest as a debt-holder before its interest as an equity-holder. This seems to be confirmed by the fact that firms with close bank ties paid higher interest rates than 'independent' firms: a premium of 
more than 50 basis points in 1977, and still as large as nearly 30 basis points in 1986 . This could appear strange in view of the fact that the main bank was in most cases also the largest shareholder (see Table 3) and therefore had an interest in the firm's profitability.

This observation raises a further question: whether banks buy shares to protect their rights as debt-holders, or to enjoy profits, as any other shareholder. Prowse (1995), who addresses this problem, finds that banks' shareholdings are significantly correlated with their lending to the firm; but, more importantly, the correlation becomes even more significant for those firms that operate in more risky environments, where 'asset substitution' ${ }^{17}$ by shareholders is more likely to occur (for instance in firms that have relatively high $R \& D$ expenses.) To protect their position as lenders from asset substitution policies, banks tend to increase their power in the firm vis-à-vis incumbent managers. This is consistent with the view that banks place their interests as lenders before any other business connection. Shareholdings are considered as an instrument to protect their main concern: their credits.

\section{THE IMPORTANCE OF INFORMAL RELATIONS: THE CASE OF JAPAN AND ITALY}

The ability of a LSH to control a firm does not depend only on the number of shares it owns directly, but also on the informal relations that are set up among shareholders both through voting agreements and through indirect ownership. In many instances these relations have grown endogenously to address particular corporate governance problems; their presence alters the relative power of shareholders, and thus the benefits and costs of the presence of a LSH. To the extent that it is difficult to have a single LSH that owns the firm and has the right incentives to monitor management, these informal relations are set up to surrogate for a stable and concentrated ownership structure that could otherwise not be established. These considerations on informal relations are not only important to understand how a bank or another LSH exerts its power in a firm, but also they have deep implications for policy options. We shall discuss two cases where these informal relations are particularly important: Japan and Italy.

We saw above that banks are the largest equityholders in Japan, owning more than 25 per cent of all outstanding shares (see Table 7.) The role of banks as shareholders, however, should be understood in the broader perspective of the inter-corporate shareholdings that characterize the ownership structure of Japanese firms. Inter-corporate shareholdings give rise to a particular type of corporate grouping that shapes the relations among most Japanese 
firms: the so-called keiretsu (or kigyo shudan). Table 8 shows these relations in six of the major

TABLE 7

OWNERSHIP OF COMMON STOCK IN MAJOR INDUSTRIAL COUNTRIES (PERCENTAGES)

\begin{tabular}{|c|c|c|c|c|c|c|}
\hline \multirow[t]{2}{*}{ TYPE OF OWNER } & \multirow[t]{2}{*}{ UNITED STATES } & \multirow{2}{*}{$\begin{array}{c}\text { UNITED } \\
\text { KINGDOM }\end{array}$} & \multirow[t]{2}{*}{ JAPAN } & \multirow[t]{2}{*}{ GERMANY } & \multicolumn{2}{|c|}{ ITALY } \\
\hline & & & & & $\begin{array}{l}\text { All listed } \\
\text { companies }\end{array}$ & $\begin{array}{c}\text { listed } \\
\text { companies } \\
\text { except banks }\end{array}$ \\
\hline $\begin{array}{l}\text { Financial } \\
\text { institutions }\end{array}$ & 30.4 & 60.8 & 47.0 & 22 & 13.9 & 6.0 \\
\hline Banks & 0 & 0.9 & 25.2 & 10 & 10.9 & 2.8 \\
\hline $\begin{array}{l}\text { Insurance } \\
\text { companies } \\
\end{array}$ & 4.6 & 18.4 & 17.3 & 12 & 0.8 & 0.8 \\
\hline Pension funds & 20.1 & 30.4 & 0.9 & & - & - \\
\hline \begin{tabular}{|l} 
Other \\
\end{tabular} & 5.7 & 11.1 & 3.6 & & 2.2 & 2.4 \\
\hline $\begin{array}{l}\text { Non financial } \\
\text { institutions }\end{array}$ & 69.7 & 26.9 & 48.8 & 78 & 81.8 & 88.7 \\
\hline Corporations & 14.1 & 3.6 & 25.1 & 42 & 21.6 & 27.3 \\
\hline State & 0 & 2.0 & 0.6 & 5 & 28.0 & 26.8 \\
\hline Individuals & 50.2 & 21.3 & 23.1 & 17 & 32.2 & 34.6 \\
\hline Foreign owners & 5.4 & 12.3 & 4.2 & 14 & 4.3 & 5.3 \\
\hline
\end{tabular}

Sources: for the USA, US Federal Reserve Flow of Funds, 1990; for Germany, Deutsche Bundesbank, Monthly Report, 1990; for Japan and the UK (years 1990-1991), Kester (1992); for Italy, Barca et al. (1994).

Japanese corporate groups in 1980. There are two distinct features of this type of organization: first, each group includes a major commercial bank (city bank) which acts as the major lender for the group's firms, or implicitly guarantees loans for the group's firms from other lenders; second, there are reciprocal shareholdings between firms of the same group, in particular with respect to the city bank which is at the same time a shareholder of the group's firms (in most cases the largest, see Table 8), a provider of funds, (in most cases also the largest, see Table 8), and is owned by firms in the group.Therefore, even in cases where a 'main bank' is the largest shareholder of a firm, it would not be correct to define such firms as 'bank-owned': the connection is, in fact, much more intertwined and involves a two-sided relationship. This is confirmed by the fact that the group's policy is not only a matter for the 
bank: for instance, in the case of financial keiretsu, these issues are discussed in the 'Presidents' Clubs', which are composed of the presidents of the major members of the keiretsu.

\begin{tabular}{|c|c|c|c|c|c|c|c|}
\hline \multicolumn{8}{|c|}{$\begin{array}{c}\text { TABLE } 8 \\
\text { JAPAN: SiX MAJOR CORPORATE GROUPS (KEIRETSU) IN } 1980\end{array}$} \\
\hline & Mitsui & Mitsubishi & Sumitomo & Sanwa & Fuyo & Ikkan & total \\
\hline $\begin{array}{l}\text { Number of firms } \\
\text { in the group }\end{array}$ & 24 & 28 & 21 & 40 & 29 & 45 & 182 \\
\hline $\begin{array}{l}\text { Intra-group } \\
\text { shareholdings }(\%)\end{array}$ & 17.4 & 29.3 & 26.8 & 16.8 & 16.2 & 14.7 & \\
\hline $\begin{array}{l}\text { Intra-group } \\
\text { bank finance }(\%)\end{array}$ & 19.1 & & 27.8 & 27 & 18.8 & 13.2 & \\
\hline $\begin{array}{l}\text { Intra-group } \\
\text { directorate holdings }(\%)\end{array}$ & 3.8 & 24.9 & 13.4 & 5.8 & 4.2 & 8.2 & \\
\hline $\begin{array}{l}\text { Weight of group in the entire } \\
\text { non financial sector } \\
\text { - in terms of assets }(\%)\end{array}$ & 2.47 & 13.1 & 1.52 & 3.01 & 2.79 & 4.03 & 15.34 \\
\hline - in terms of profits $(\%)$ & 2.54 & 2.89 & 1.28 & 2.22 & 1.52 & 3.05 & 12.84 \\
\hline - in terms of employees $(\%)$ & 0.75 & 1.84 & 0.43 & 1.24 & 1.03 & 1.57 & 4.91 \\
\hline
\end{tabular}

Source: Aoki (1984a)

There are many explanations for the existence of keiretsu groups $^{18}$. Our interest here is in understanding how such an arrangement could arise endogenously to guarantee stability and ownership concentration. In the immediate postwar period the US Commander for Allied Powers led a reform of the Japanese corporate structure aimed at dissolving the zaibatsu holdings, and at establishing a US-type corporate governance system, where the market for corporate control was to play a major role. A strict regulation of ownership was introduced: the 1947 anti-trust Law prohibited industrial companies from holding stocks, and restricted financial institutions other than banks from holding more than 5 per cent of a given company; the Security Trade Act, also introduced in 1947, prohibited banks from underwriting, holding, or even dealing in corporate securities ${ }^{19}$. After the stock market collapse in 1949, these regulations were loosened, and institutional ownership was allowed in an attempt to stabilize share prices. ${ }^{20}$ This, however, was not enough to guarantee stability in the control of firms as it became clear (see Aoki, 1984a) in 1965, when at the same time there was a stock market plunge and a liberalization of capital inflows, giving rise to the threat of takeovers and thus of a change in established control groups. As a reaction, major corporations started to built up 
mutual shareholdings in order to insulate themselves from the market for corporate control. These connections produced two results. They fostered co-operation among shareholders, giving them a better opportunity to act as a single LSH (see for instance the Presidents' Clubs); they also secured established control, and thus made insiders able to commit to long term relations.

The second reason why these mutual ownership structures and informal relations among shareholders were established, was to limit the power of banks in the management of firms. As we argued in the previous paragraph, banks, as lenders, are mostly concerned with the bottom tail of the distribution of returns. Since in the keiretsu banks have an important, but not exclusive, role in the control of firms, this bias is limited.

In Italy too, special relations among shareholders arose as a 'substitute' for ownership concentration and other corporate governance devices. The case of Italy deserves particular attention also because in recent years the country's privatization program has frequently stumbled on the question of what is the proper ownership structure once control in transferred from the state to private shareholders.

The Italian public enterprise sector has traditionally been larger than in other major OECD countries: the state was not only present in the utility sector; almost all banks, the largest insurance companies and a relevant share of industrial firms were state-owned. Yet, since 1990, the picture has begun to change: between 1992 and 1995, sales of state-owned firms amounted to one half of 1 per cent of 1993 GDP. However, the most ambitious part of the privatization program is still to be implemented: thus Italy will be, in the near future, the European country most involved in privatizations. Corporate governance issues are thus relatively more urgent in Italy than elsewhere -- a fact explicitly recognized, for instance, by the Banca d'Italia:

"...the [privatization] program places special emphasis on the need to attain stable configurations for the property structure of privatized companies, so as to ensure efficient mechanisms of corporate governance. Such objective is to be achieved by carefully identifying, on a case by case basis, the most suitable form of property structure for the enterprises to be privatized..." ${ }^{21}$

As in the case of Japan, the statistical indicators that were presented above, do not provide a truthful picture of the ownership structure of Italian firms, because of the presence of indirect relations among shareholders that influence the way in which corporate control is exercised. 
Yet, the relations among firms are different from those that occur in the keiretsu groups: most Italian listed companies are linked through so-called pyramidal groups.

TABLE 9

SEPARATION BETWEEN OWNERSHIP AND CONTROL THROUGH PYRAMIDAL GROUPS IN ITALIAN COMPANIES (weighted percentages)

\begin{tabular}{|c|c|c|c|c|c|c|}
\hline \multirow{2}{*}{$\begin{array}{c}\text { Characteristics of the company at } \\
\text { the head of the group }\end{array}$} & \multicolumn{3}{|c|}{ Control structure } & \multicolumn{3}{|c|}{ Control-ownership leverage } \\
\hline & 1991 & 1992 & 1993 & 1991 & 1992 & 1993 \\
\hline Non banking private sector & 47.6 & 45.7 & 43.3 & 8.4 & 7.6 & 7.9 \\
\hline Individuals and partnerships & 12.3 & 12.2 & 11.2 & 4.4 & 4.2 & 4.0 \\
\hline $\begin{array}{l}\text { Limited partnerships and limited } \\
\text { liability companies }\end{array}$ & 22.1 & 20.2 & 19.4 & 11.1 & 9.2 & 9.7 \\
\hline Other limited companies & 1.9 & 1.9 & 1.6 & 2.6 & 2.1 & 2.3 \\
\hline Coalitions & 12.3 & 11.4 & 11.1 & - & - & - \\
\hline $\begin{array}{l}\text { State companies other than state- } \\
\text { controlled banks }\end{array}$ & 42 & 41.7 & 40.5 & 1.7 & 1.7 & 1.9 \\
\hline Banks & 6.7 & 9.1 & 12.7 & 1.2 & 1.3 & 1.5 \\
\hline of which : state owned & 5.4 & 7.8 & 11.9 & 1.1 & 1.3 & 1.5 \\
\hline Private & 1.3 & 1.3 & 0.8 & 1.4 & 1.4 & 1.3 \\
\hline Foreigh control & 2.7 & 3.4 & 3.6 & 1.9 & 1.9 & 2.3 \\
\hline Total & 100 & 100 & 100 & 2.7 & 2.5 & 2.7 \\
\hline
\end{tabular}

Source: Barca (1994.)

A pyramidal group is a situation in which many companies are controlled by the same entrepreneur through a chain of control relations: firm $A$ controls 51 per cent of firm $B$ 's outstanding equity, and firm $B$ controls 51 per cent of firm $C$ : therefore firm $A$ controls firm $C$. This arrangement, that may comprise hundreds of firms, allows an 'artificial' ownership concentration: although the entrepreneur, through his indirect shareholdings, has complete control of all the firms in the group, the amount of equity provided is limited: in the case above, only 26 per cent of $C$ pertains to $A$. As Barca et al. (1994) and Barca (1995) report, around 35 per cent of Italian small companies (from 50 to 100 employees) and a fraction from 60 to 85 per cent of medium size companies are controlled by a group ${ }^{22}$. It is, however, for 
very large companies, especially listed ones, that the pyramidal organization is most employed, so that almost all of them are part of a group. The authors were able to map the ownership relations of a vast group of firms: considering the 258 companies listed on the Milan Stock Exchange, and the ownership structure of the firms that own or are owned by them (a total of 6,500 firms, of which 4,200 Italian), 178 pyramidal groups emerged.

Besides direct ownership, it is therefore interesting to see who holds the ultimate control of a firm, and how this power is related to direct or indirect equity holdings in the firm. Barca et al. show that this type of corporate system results in the separation between ownership and control. Table 9 is very clear in this respect: insiders (that is shareholders at the head of the groups) for each unit of capital provided are able to control 2.7 units of the capital of the group; outstanding cases are those of the De Benedetti group where insiders, for each unit of capital, controlled 25 units, and the limited partnership Giovanni Agnelli \& C whose controlownership leverage was $17^{23}$.

Thanks to pyramidal groups, entrepreneurs, or groups of entrepreneurs, succeed in raising capital in the equity market without losing control of the firm: although this may produce beneficial effects, because it limits free-rider problems, it weakens the incentives of these 'LSHs': they have large voting power, but, paradoxically, they do not enjoy, in proportion, the profits of the firms they control; therefore they run into the same moral hazard problems that a pure non-equity-holder-manager suffers, or even worse. In such pyramidal groups, in fact, there are many harmful moral hazard opportunities: for example, in the determination of transfer prices among firms inside the group, or in the setting of other business relations. Thus entrepreneurs - and this is the reason why they create 'pyramidal groups' - seek to extend their control over a very wide range of firms: this allows them to enjoy more private benefits. Since control is exercised with a relatively small share of capital of the group, they can extract these private rents at the expense of the profitability of the firm: obviously all of this is at the expense of smaller shareholders, who are excluded from these private benefits and can only enjoy profits.

The Italian experience confirms that it is not sufficient to establish a concentrated ownership structure to solve moral hazard problems: the LSHs, in order to be effective monitors, should have proper incentives. Pyramidal groups, while allowing the control of firms to be concentrated, do not provide the ultimate owners with the right incentives: in the example above, firm B could be seen as the LSH of firm C; however, firm B was only an instrument through which firm A could control firm $\mathrm{C}$ with relatively limited equity exposure. As a general lesson, we can draw the conclusion that, to understand whether concentrated 
ownership is beneficial, it is necessary to penetrate the veil between firms and their ultimate owners that is established via indirect equityholdings and other informal arrangements.

\begin{tabular}{|c|c|c|c|c|}
\hline \multicolumn{5}{|c|}{$\begin{array}{l}\text { THE CONTROL OF INDUSTRIAL COMPANIES IN ITALY (1993) } \\
\text { (PERCENTAGES) }\end{array}$} \\
\hline \multirow[t]{3}{*}{ MODELS OF CONTROL } & \multicolumn{2}{|c|}{$\begin{array}{l}\text { Industrial companies with more than } 50 \\
\text { employees (stratified random sample) }\end{array}$} & \multicolumn{2}{|c|}{$\begin{array}{l}\text { Industrial companies with } 20 \text { to } 500 \text { employees } \\
\text { ( } 300 \text { selected companies) }\end{array}$} \\
\hline & \multicolumn{2}{|c|}{$\begin{array}{l}\text { According to models employed in each } \\
\text { individual company }\end{array}$} & $\begin{array}{l}\text { According to models } \\
\text { employed in each } \\
\text { individual company }\end{array}$ & $\begin{array}{l}\text { According to models } \\
\text { employed in the 'head' } \\
\text { of group (if any) }\end{array}$ \\
\hline & unweighted & weighted & \multicolumn{2}{|c|}{ unweighted } \\
\hline Absolute control & 13.8 & 8.8 & 18.5 & 19.9 \\
\hline Family control & 32.1 & 16.6 & 53.5 & 60.1 \\
\hline Coalition control & 13.7 & 9.9 & 10.5 & 14 \\
\hline $\begin{array}{l}\text { Financial supervision } \\
\text { control }\end{array}$ & 0.2 & 0.2 & 0.7 & 0.7 \\
\hline State ownership & 6.9 & 15.9 & 2.1 & 2.1 \\
\hline Group control & 33.3 & 49.0 & 14.7 & - \\
\hline Not identified & - & - & - & 3.2 \\
\hline Total & 100 & 100 & 100 & 100 \\
\hline
\end{tabular}

Source: Barca (1995.)

The high ownership concentration of Italian firms does not prevent moral hazard problems. Zingales (1994) observes that while in other markets voting shares trade at a premium of 10 to 20 per cent above non voting shares, in Italy such a premium is as high as 85 percent: this can be interpreted as evidence that who controls a firm has more opportunities to seize the private benefits of control. Nicodano (1993) finds that the ownership structure of Italian companies helps to explain these high voting premia: when a firm belongs to a pyramidal group expected premia are higher.

To understand the behaviour of such LSH - that is the heads of the pyramidal groups - it is necessary to look inside them and to analyze who controls them, and how such control is exercised. Barca (1995) reports that 41 per cent of the companies at the head of a pyramidal group are under 'family control', that is an arrangement in which the 'owners belong to the 
same family as the entrepreneur' ${ }^{24}$, and 19 per cent of the firms is controlled through 'coalition control', that is through binding voting agreements, patti di sindacato (see Table 19). Therefore, behind the pattern of direct ownership concentration, there is a complex nexus of relations among shareholders that significantly alters the picture. First of all, the chains of control, which allow some entrepreneurs to control firms with very limited provision of equity finance; second, the fact that in many instances, especially at the top of these chains of indirect shareholdings, control takes place through informal relations among shareholders: mostly, insiders are linked by family bonds.

\section{E PRIVATIZATION AND OWNERSHIP STRUCTURE: LESSONS AND POLICY IMPLICATIONS.}

The role of the government when the ownership structure is endogenous. Lessons from the Japanese post-war experience

From the examples of Japan and Italy we can draw two lessons. First, when the presence of a LSH or of direct ownership concentration cannot be established, it does not necessarily follow that a market for corporate control will automatically arise, as an alternative corporate governance device. The two cases analyzed above show that ownership concentration may be mimicked through informal relations among shareholders, leading to the concentration of control. Such concentration, however, does not provide proper incentives to the agents that are responsible for exercising control. Usually these informal relations are not visible at first sight: this is, for example, the case of Italy, where statistical indicators show very high ownership concentration levels, but behind the legal 'veil' of pyramidal groups lies a substantial separation between ownership and ultimate control. Thus, when the choice of the best ownership structure in a privatization process is at stake, governments should carefully consider the possibility that such informal relations may arise, and their consequences on the corporate governance structure of the privatized company.

The second lesson follows as a consequence of the first: it is very difficult "to lean against the wind". The ownership structure that characterizes the firms of a particular country is often an endogenous variable; attempts to establish exogenously a different equilibrium may fail, or produce undesired outcomes. Japan provides an extraordinary example: contrary to the intentions of the US administrators, who tried to set up a US-type, market-based, 
corporate system, and strongly opposed an active role of institutional investors, the final outcome was the so called 'main bank system'.

Up to 1949 , as we have seen, a series of attempts were put in place to establish a UStype corporate system. This was to be realized not only through straightforward limitations on the maximum share of ownership rights that any single investor could hold, but also through an educational campaign aimed at channelling small savers' investments in the stock market, and through financial support to employee ownership. The peak of this process was reached in 1949. Apparently, the reform was successful, since in a few years a widespread ownership structure was established: 13 per cent of the shares of listed companies was owned by securities companies, 70 per cent by individuals; in a single month, September 1949, 27 per cent of total disposed stocks was sold to employees. This result was particularly noteworthy, since in 1945 individuals held only 53 per cent of total outstanding stocks and securities, and corporations 2.8 per cent (see Table 11).

Behind the surface, however, the reform did not succeeded in establishing an efficient corporate governance system. In 1949, for example, only 250 of the 453 listed companies paid dividends. When a fiscal stabilization program was introduced, in August 1949, and the soft budget constraint of firms was tightened (reduction of subsidies, higher interests rates, curbs on controlled prices) the stock market collapsed. This was the turning point: in order to

\begin{tabular}{|c|c|c|c|c|c|c|}
\hline \multicolumn{7}{|c|}{$\begin{array}{c}\text { TABLE } 11 \\
\text { OWNERSHIP STRUCTURE OF POSTWAR JAPANESE } \\
\text { LISTED COMPANIES (PERCENTAGE OF COMPANIES' CAPITAL) }\end{array}$} \\
\hline $\begin{array}{ll}\text { Category of } \\
\text { investor }\end{array}$ & 1945 & 1949 & 1951 & 1953 & 1955 & 1960 \\
\hline Government & 8.3 & 2.8 & 1.8 & 0.7 & 0.4 & 0.2 \\
\hline $\begin{array}{l}\text { Financial } \\
\text { institutions }\end{array}$ & 11.2 & 9.9 & 18.2 & 22.9 & 23.6 & 30.6 \\
\hline Trust banks & - & - & 5.2 & 6.7 & 4.1 & 7.5 \\
\hline $\begin{array}{l}\text { Securities } \\
\text { companies }\end{array}$ & 2.8 & 12.6 & 9.2 & 7.3 & 7.9 & 3.7 \\
\hline $\begin{array}{l}\text { Other } \\
\text { companies }\end{array}$ & 24.6 & 5.6 & 13.8 & 13.5 & 13.2 & 17.8 \\
\hline Foreign & - & - & 1.8 & 1.7 & 1.7 & 1.3 \\
\hline Individuals & 53.1 & 69.1 & 57.0 & 53.8 & 53.2 & 46.3 \\
\hline
\end{tabular}

Source: Bank of Japan (1970), as reported in Miyajima (1994.) 
support stock prices, the rules were relaxed, and more freedom to buy shares allowed to financial institutions: in 1953 the Antitrust Law was changed, raising the limit to which financial institutions were subject in the amount of equity of a single company that they could own, from 5 to 10 per cent. As can be seen from Table 11, this implied an abrupt change in the ownership structure of Japanese firms. In 1949, financial institutions held only 9.9 per cent of listed companies' capital; in 1960 they held more than 30 per cent; on the contrary, individuals' shareholdings fell from 70 to 46.3 per cent. Moreover, small shareholders, frightened by the stock market collapse, did not prove to be long-run investors: only 50 per cent of the employees that had bought shares the year before the market crash held their shares for more than two years. The assumption that, once ownership rights were adequately dispersed and ownership concentration forbidden, a market for corporate control would naturally develop proved wrong.

Italy provides another example of an endogenous ownership structure. In the recent privatization of two of the main Italian banks (Banca Commerciale Italiana and Credito Italiano) the government attempted to establish a dispersed ownership structure. However, immediately after the privatization, a small group of shareholders seized control of the banks through informal voting agreements, establishing a control structure which is much more consistent with the Italian corporate environment. Table 12 shows some data from the Italian firms so far privatized through a public offer ${ }^{25}$ : the numbers show that, in all instances, the number of shareholders rapidly shrunk; and, more importantly, that only a very small fraction of them voted in shareholders' meetings. The concentration of control in the hands of a small group of pooled investors emerged endogenously due to the passive role of individual shareholders.

\section{Banks and policy options}

Given this evidence, many recent papers have focused on the endogeneity of the ownership structure of firms. This stream of research is yielding new insights into the effectiveness of government intervention in corporate governance matters. According to what Oliver Hart (1995) calls the 'Chicago view', the market should reach the first best ownership distribution regardless of initial allocations. At the time of listing a company, its original owners should have incentives to choose the best allocation of ownership rights, i.e. the one that maximizes the value of the firm, since this also maximizes the price at which they can sell their shares. Any mistake, however, will be corrected by the market because a rider would find it profitable to seize control of the firm and change its ownership structure: as Shleifer and Vishny (1995) point out "takeovers can be viewed as a rapid-fire mechanism for ownership concentration." 
This is true for ownership rights, but also, at least in principle, for all the other variables that affect the value of the firm, such as statutory procedures for the resolution of conflicts among shareholders, the choice of managers etc.

\begin{tabular}{|c|c|c|c|c|}
\hline \multicolumn{5}{|c|}{$\begin{array}{c}\text { TABLE } 12 \\
\text { THE ITALIAN PRIVATIZION PROGRAMME 1993-95: } \\
\text { COMPANIES SOLD THROUGH A PUBLIC OFFER }\end{array}$} \\
\hline Company & Credit & Comit & IMI & INA \\
\hline Number purchasers & 190,000 & 297,527 & 355,000 & 417,720 \\
\hline $\begin{array}{l}\text { number of shareholders after three } \\
\text { months }\end{array}$ & 112,000 & 232,000 & 217,000 & 403,000 \\
\hline number of shareholders & $176,866(1)$ & $175,981(2)$ & n.a & $170,000(3)$ \\
\hline $\begin{array}{l}\text { number of shareholders at the first } \\
\text { sharholders' meeting }\end{array}$ & 329 & 1839 & 74 & 2238 \\
\hline as \% of outstanding equity & 23.1 & 28.8 & 60.2 & 57 \\
\hline \multicolumn{5}{|l|}{ The 10 largest shareholders: } \\
\hline as $\%$ of equity & 16.9 & 16.1 & 59.9 & 58 \\
\hline $\begin{array}{l}\text { as } \% \text { of equity represented at the } \\
\text { first shareholders meeting }\end{array}$ & 73.2 & 55.8 & 99.5 & n.a \\
\hline Last shareholders meeting (date) & 29-4-1995 & $29-4-1995$ & $24-7-1995$ & $11-1-1996$ \\
\hline $\begin{array}{l}\text { Number of shareholders at the last } \\
\text { shareholders' meeting: } \\
\text { present } \\
\text { postal votes } \\
\text { total }\end{array}$ & $\begin{array}{l}356 \\
139 \\
495 \\
\end{array}$ & 659 & 371 & $\begin{array}{l}644 \\
4 \\
648\end{array}$ \\
\hline As \% of outstanding ordinary shares & 17.21 & 25.51 & 66.6 & 51.52 \\
\hline \multicolumn{5}{|l|}{$\begin{array}{l}\text { The ten largest shareholders present } \\
\text { at the meeting }\end{array}$} \\
\hline $\begin{array}{l}\text { As \% ot total equity (ordinary } \\
\text { shares) }\end{array}$ & $8.01(4)$ & $8.94(5)$ & $45.57(6)$ & 49.39 \\
\hline $\begin{array}{l}\text { As } \% \text { of equity represented at the } \\
\text { last shareholders' meeting }\end{array}$ & 46.54 & 35.28 & 68.42 & 95.87 \\
\hline
\end{tabular}

(1) As of 29/4/1995

(2) As of 29/4/1995. It includes:

175,000 double votes (par value Lire 1000)

376 single vote (par alue Lire 500)

175,981 Total

(3) As of 30/1/1996

(4) Includes shareholders with more than $2 \%$ (that is 3 shareholders: Commercial Union $2.02 \%$, Franco Tosi $3.00 \%$, Allianz $2.99 \%$.

(5) Includes shareholders with more than $2 \%$ (that is 3 shareholders: Generali, Commerz Bank, Paribas with approximately $2.98 \%$ each.

I.R.I. (2.1\%) did not exercise its voting rights.

(6) Includes 7 shareholders.

(7) The four largest shareholders as of 10/03/1996, are: Ministero del Tesoro 34.38\%, CARIPLO 3\%, Gruppo S.Paolo 3\%, IMI 3\%.

Source: INA investors Relations 
This view does not deny the relevance that government intervention may have: however it suggests that only policies that affect the structure of financial markets are effective. For example, in the attempt to establish a US-type financial system, the government can not choose directly the ownership structure of a firm (the cases of Comit and Credit are instructive); but it can establish the conditions in which such a system may emerge.

In this sense reforms for the development of the financial institutions that can play the role of efficient LSH. As we discussed in the previous sections, the characteristics of LSHs are

a critical variable for the success of a privatization program. The reality of continental Europe is that the financial systems are dominated by banks: yet, these institutions are ill-suited to act as 'virtuous controlling shareholders' because of the conflict of interest that may arise with their lending activity. For this reason it is often argued that continental European governments should foster the development of new types of financial investors - pension funds in particular, but also mutual funds. However, the experience so far has been that setting up these institutions requires time - often a lot of time (this for example has been the recent experience of mutual funds and pensions funds in Italy.) If privatizations had to wait until these new creations were strong enough to take up a relevant position in the financial system, they might be delayed for years. In the short run, there may be no better alternative to working with what already exists: banks.

Banks play a double role during a privatizations process. They are one of the objects of the process, since in many countries - Spain, France and Italy in particular - a significant fraction (about two-thirds in Spain and Italy) of the banking industry is public. But banks could also be important buyers of the equity of industrial firms sold by the government, since in continental Europe they manage the largest part of private savings. Clearly these two sides of the coin are intimately related: a good bank privatization should also aim to create a potentially good buyer for other privatizations.

The French experience is particularly interesting in this respect, since while privatizing the state-owned banks the government also engaged in a reform of the banking industry. The 1984 bank law allowed French banks to buy equity of industrial firms, and authorized them to act as merchant banks. In 1986, when the privatisation process began, banks were the first asset on sale: Paribas and Indosuez, two of the banks nationalized by Mitterand in 1982, and also the three large banks nationalized by De Gaulle in 1945, BNP, Crédit Lyonnais, and Societé Générale. The newly privatized banks engaged in two types of activity ${ }^{26}$. Some large commercial banks, through their investment banking branches, acquired relevant stakes - 20 to 40 per cent - in listed companies, and began to exert a substantial influence in the firms' 
board of directors. This is the case, for instance, of the Banque Indosuez which is known to act as a very active shareholder, and took part in important financial operations such as the takeover of Societé Générale de Belgique in 1988. Other banks developed a different approach: they targeted medium and small non-listed companies. Crédit Agricole, for example, exploited its vast branch network to offer corporate governance services to local firms. The Franch experience thus seems to show that the privatisations of banks may generate positive spill-offs which extend beyond their direct role in other privatisations.

Italy, on the contrary, seems to be following quite a different path. Even though two among the country's largest banks were recently privatized, the large majority of remains public - either directly owned by the Treasury (such as Banca Nazionale del Lavoro), or controlled by public foundations (such as San Paolo di Torino, Italy's largest bank in terms of deposits.) Three facts are particularly worrying. First, the political will to sell these banks is simply not there - and the Bank of Italy seems not to dislike the presence of banks that are not driven by the need to maximize shareholder equity, and can thus be instrumental in the solution of banking crises (see for instance the recent acquisition by CARIPLO of the largest saving bank in Calabria.) Second, these banks are very far from being efficient. Third, they have become active players in other privatizations, while still being public themselves (see for instance the controlling position that CARIPLO and San Paolo have taken up in INA, the recently privatized insurance company, and in IMI, a large investment bank). Moreover, these banks seem not to care particularly about small shareholders, as recently demonstrated by the behaviour of Banca di Roma in the acquisition of the Banca Nazionale dell'Agricoltura: even though the target firm was listed, by virtue of a controversial legal arrangement the buyer avoided launching a public offer, and thus excluded outside shareholders from the offer, limiting the negotiation to the insider. The question naturally arises: are these banks good candidates to play the role of LSH?

Privatizations are a very good opportunity to set up the right environment for the development of new financial intermediaries and in general for a sound corporate governance system. Here too, the sale of companies to the market should not aim to establish directly the 'best' ownership structure: first because nobody can say which structure is best; secondly because the market could reverse the government choice if this were not consistent with the environment. On the contrary, the government should pay attention to establish the best 'rules of the game' and give to the market the right incentives: or, more realistically, avoid giving the wrong incentives. 
The introduction of the so-called 'golden share' is a good example in this sense. In many recent privatizations, the government has kept the power to intervene directly in the corporate governance of firms, even after the privatization had been completed. In France, for instance, the government has retained special rights to influence shareholders' deliberations through the so called action spécifique, which, for five years after the sale of the shares, guarantees a veto power on the sale of a block larger than 10 per cent of the firm's capital ${ }^{27}$. A similar instrument was introduced in the UK ('golden share') in many important sales of public firms ${ }^{28}$, reserving similar rights to the government.

At first sight, the rational for these provisions seems clear: they guarantee the seller that, at least for a certain period of time, it can control the outcome of the privatization. This may be particularly valuable in the privatization of firms with social importance: utilities for example, which often operate in a monopolistic regime. However, the policy-maker should compare the benefits with the costs of these instruments - and if the costs are relevant, ask whether other instruments could be used. We will not go in deep into the problem, except for mentioning that governments often privatize in order to reduce the power of politicians over the economy: it would therefore be nonsense to sell shares to private agents, leaving the ultimate power of decision over the control of the firm to public agents. This is especially because:

1. a veto power over block transfers undermines the development of a genuine market for corporate control;

2. if investors are rational, they will anticipate these moral hazard problems and agree to buy shares only at a discount. More importantly, investors would certainly refrain from buying large blocks of shares, since these may become illiquid, if the government were to veto their sale to a third party, or prevent them for exercising effective control, if the golden share also (as it does in some cases) gives the government the power to intervene in company matters.

The argument against golden shares may be strengthened in the light of the recent British experience. In the UK golden shares played an important role in the privatization of public utilities, proving, up to now, to be an effective instrument: the government wished to keep a fairly dispersed ownership structure of these companies, and has so far succeeded. Golden shares enabled the government to exercise a veto power on the acquisition of blocks of shares by private investors, and in many instances it kept the right to appoint the managers of these firms ${ }^{29}$. These rights, however, did not solve the corporate governance problems of these companies: they merely served as an 'aspirin' as long as the special rights were in place -- as became clear in the case of the 12 electricity distribution companies when the special powers granted by golden shares elapsed, on the 31st of March 1996: since then we have witnessed a surge of takeovers, in most instances hostile (see table 14) organized by electricity 
generating companies. Golden shares were used as a surrogate for antitrust regulation, and proved to be only a temporary solution for the underlying problems. The government wanted to limit vertical integration in the electricity industry - and therefore too much concentration of market power - but it failed as soon as the golden shares elapsed. After the recent wave of takeovers, the government had to resort to anti-trust regulations, and asked the Monopoly and Merger Commission to intervene. Probably it should have done this from the beginning, avoiding the temporary 'aspirin' solution.

The British experience should be carefully considered by those governments that are currently considering the introduction of golden shares in the statutes of the telephone companies that will be privatized in the near future: STET, in Italy, Deutsche Telecom in Germany, France Telecom in France. The British outcome could be avoided by making such special rights permanent (as the Italian government, for instance is considering), but this may wipe out most of the institutional demand for the shares of these companies, and, more importantly, it would make it virtually impossible to find a group of LSH with the right incentives. This experience also confirms the point made above about ownership structures being endogenous in the long run. In the British utilities case the driving force behind the establishment of an ownership structure was the search for monopolistic rents; in order to avoid them, and reach the first best equilibrium, it was not enough to set up temporary external barriers: it was necessary to act on the underlying forces through effective anti-trust regulations.

\begin{tabular}{|c|c|l|l|l|}
\hline \multicolumn{4}{|c|}{ TAKEOVERS AGAINST ELECTRICITY DISTRIBUTION COMPANIES IN THE UK } \\
\hline Raider & $\begin{array}{c}\text { Target } \\
\text { Company }\end{array}$ & $\begin{array}{c}\text { Type of } \\
\text { Takeover }\end{array}$ & \multicolumn{1}{c|}{ date } & \multicolumn{1}{|c|}{ Type of the Raider } \\
\hline Trafalgar House & Northern Electric & obstile & $19 / 12 / 95$ & holding company \\
\hline Southern Power & SWEB & obstile & $10 / 07 / 95$ & $\begin{array}{l}\text { electric utility (production } \\
\text { and distribution) }\end{array}$ \\
\hline Scottish Power & Main Web & obstile & $24 / 07 / 95$ & $\begin{array}{l}\text { electric utility (production } \\
\text { and distribution) }\end{array}$ \\
\hline Hanson & Eastern Group & friendly & $31 / 07 / 95$ & electric utility (production) \\
\hline North West & Norweb & friendly & $8 / 09 / 95$ & \begin{tabular}{l} 
electric utility (distribution) \\
\hline Waler
\end{tabular} \\
\hline PowerGen & midlands & friendly & $18 / 09 / 95$ & electric utility (distribution) \\
\hline
\end{tabular}

Source: F. Lo Passo and A. Macchiati (1996) 


\section{F CONCLUSIONS}

At the beginning of this paper we posed a question: "can we trust banks when they sit on the board of directors?". As we saw, the answer is not unambiguous. The type and degree of a bank's monitoring activity is deeply influenced by its lending activity. A bank tends to protect its credits and thus to minimize the probability of default; a lender derives no benefits from extra profits since its payoff is limited in good states of nature. This is not to say bank monitoring cannot be useful. In a mature industry, say the steel industry, a bank could do a very good job, and the side effects would be limited since extra profits are in any case very small. But many entrepreneurial activities will not take off - for example when new technologies are at stake- if financiers are not ready to take risks. In such cases an efficient market for corporate control is the best mechanism to allocate resources: it would not only serve as a market for equity stakes, but also as a market for entrepreneurial ideas since financial projects would be evaluated by many independent analysts. A too close firm-bank relationship hinders the development of such a market because the bank may use its lending power to entrench its control. This is the reason for keeping a wary eye on 'banks on the board of directors'.

In this context, what is the role of government? We saw that the ownership structure of a firm is an endogenous variable, which cannot, especially in the long run, be determined by the government. The endogenous equilibrium of an ownership structure, however, may be socially inefficient in the absence of perfect information, and in the presence of unforseable contingencies: for this reason there remains scope for government intervention, particularly at the time of a privatization. The government, however, should aim not at determining directly the ownership structure of firms: it should rather aim at creating the best environment in which the market equilibrium can coincide with the socially optimal equilibrium. It thus is important to establish appropriate 'rules of the game', especially in the privatization of public utilities. Financial market reforms should aim at establishing an environment in which market forces contribute to reach the socially efficient equilibrium.

We have used the example of Italy to illustrate some of these issues. The privatization of banks in Italy is the first step in the construction of a sound corporate environment. However, it will not be sufficient. The Italian banking sector is heavily regulated. Up until now the role of regulator has been performed by the central bank which has very strong powers: since, for example, it approves bank mergers and acquisitions and it can influence the behaviour of banks. But in this supervisory activity the Bank of Italy has proved to be more interested in the stability of the banking system than in its efficiency. The problem is not the quality of the supervisory authority, but a conflict of interest between the stability of the 
system and its efficiency ${ }^{30}$. We can conclude that the sale of bank shares to private investors is insufficient to shape efficient banks and more effective corporate governance structures. 


\section{NOTES}

${ }^{1}$ Quoted from J. Bredford De Long (1991), page 215.

${ }^{2}$ See A. D. Chandler (1990).

${ }^{3}$ It. should be stressed that US investment banks and German Grossbanken financed their activity in a very different way.

${ }^{4}$ It should also be noted that $50 \%$ of the Merceders Holding A.G. is owned by Stella and Stern Automobil beteiligungs gesellshaften $\mathrm{mbH}$ and Commerzbank, Dresdner bank and the Bayerishe Landesbank Girozentrale own $25 \%$ each of these two companies (these data refer to 1991).

${ }^{5}$ Aoki (1996), page 9.

${ }^{6}$ Jensen and Mackling (1976), page 311.

${ }^{7}$ As reported by Kaplan (1993), the typical top Japanese executive holds half of the ownership stake of the typical U.S. top executive, when only shares are considered, and one quarter when options are included.

${ }^{8}$ See for example the role performed by institutional investors in the recent Granada-Forte case in the UK.

${ }^{9}$ See for example McConnel and Servaes (1990) for a paper which employs a similar methodology (it studies the relation between the Tobin's q and insiders' equity). Contrasting results are

shown by Demsetz and Lehn (1985): they find no significant relation between firm profitability and ownership concentration. However, contrary to almost all other empirical studies, they postulate a $l i$ near relation which is ill-suited to capture the non linear, non monotone relation found in the other studies. A different methodology is used by Slovin and Sushka (1993): see the text above.

${ }^{10}$ Since both Tobin's q and the ownership structure are endogenous variables, there is a problem as to whether ownership concentration affects firm value, or firm value affects the equilibrium ownership structure.

${ }^{11}$ See Stulz (1988).

${ }^{12}$ Prowse's sample consists of the firms that Nakatani (1984) defines as members of a keiretsu, for which both share and debt holdings are available.

${ }^{13}$ See Edwards and Fisher (1994)

${ }^{14}$ See Edwards and Fisher (1991)

${ }^{15}$ See Kaplan (1993a), Kaplan (1993b), and Kaplan and Minton (1994)

${ }^{16}$ Kaplan and Minton (1993), page 14.

17 Shareholders, once they are granted a bank credit, and given the expected value of potential investments, tend to invest in projects with high pay-offs and high probability of default. This happens because of the structure of their pay-offs: if the outcome of the investment is good, they gain most of the profits since they are the residual claimant; if instead the outcome is bad, because of limited liability, they suffer only part of the losses. This phenomenon is generally referred to as 'asset substitution'.

${ }^{18}$ See for instance Nakatani (1984).

${ }^{19}$ For details see Miyajima (1995)

${ }^{20}$ However, a bias against ownership concentration remained, and still in today's Japan there are limits in this sense: because of the Anti-Monopoly Act, banks cannot hold more than 5 per cent of any single company -- up to 1987 the limit was 10 per cent; for insurance companies it is still 10 per cent.)

${ }^{21}$ Banca d'Italia (1994), page 16.

${ }^{22}$ The authors do not consider the entire population of firms but a large sample.

${ }^{23}$ These data come from Barca (1995).

${ }^{24}$ Barca (1995) page 16.

${ }^{25}$ The public sale of shares of IMI and INA was only partial: privatization was subsequently completed through a private placement.

${ }^{26}$ The following information on French banks is from Cardilli, Pinzani and Signorini (1994.) 
${ }^{27}$ The action spécifique was introduced in the privatization of Matra, Havas, Elf-Aquitaine and Bull. ${ }^{28}$ Britoil, British Telecom, British Gas, Enterprise Oil.

${ }^{29}$ A veto power on sales of blocks of shares was introduced in the statutes of British Telecom, Cable and Wireless, National Power, and PowerGen; the right to nominate managers, for example, in the cases of British Telecom, and Cable and Wireless.

${ }^{30}$ Battaglini (1996) studies the relation between prudential regulation and ownership structure of banks. 


\section{REFERENCES}

Aghion P. and Tirole J. (1994), "Formal and real authority in organisations", M.I.T working paper, No. 94-13.

Aoki M. (1984), The economic analysis of the Japanese firm, Elsevier Science Publishers.

Aoki Masahico (1996), "Controlling Insider control: issues of Corporate Governance in Transition Economies", in M. Aoki (ed.) Corporate Governance in Transition Economies: Insider Control and the role of Bank, The World Bank.

Banca d'Italia (1994), Foreign Department, "Report on Italy's privatisations program", mimeo.

Banca d'Italia (1994), Il mercato della proprietà e del controllo delle imprese: aspetti teorici e istituzionali, numero speciale dei "Contributi all'analisi economica".

Bank of Japan (1970), Economic statistics since the Meiji Era. Tokio.

Barca F. (1995), "On corporate governance in Italy: issues, facts and agenda", mimeo.

Barca F., Bianchi M., Brioschi F., Buzzacchi L.,Casavola P., Filippa L., Pagnini M., (1994), Assetti proprietari e mercato delle imprese. Gruppo, proprietà e controllo nelle imprese italiane medio grandi, vol.II, Bologna, Il Mulino.

Battaglini M. (1996), "Assetti proprietari e regolamentazione delle banche", Ricerca di Base, n.19, Università Bocconi.

Berle A. A. and Means G. C. (1932), The modern corporation and private property, New York, Macmillan.

Bhagat S. and Brickley J (1984), "Cumulative voting: the value of minority shareholder voting rights", Journal of Law and Economics, 27, pp.339-365.

Bhushan R. (1989), "Firm Characteristics and Analysyst Following", J.Accounting and Econ. 11: $255-74$

Brickley J.A.,Lease R.C and Smith C.W. (1988), "Ownership structure and voting on antitakeover amendments", Journal of Financial Economics, 20, pp.267-291.

Burkart M., Gromb D. and Panunzi F. (1994), "Large shareholders, monitoring and fiduciary duty", mimeo, IGIER.

Cardilli D., Pinzani L and Signorini P.E. (1994), "Mercato e istituzioni della riallocazione proprietaria in Germania, Regno Unito e Francia" in numero speciale dei Contributi all'analisi economica, Il mercato della proprietà e del controllo delle imprese: aspetti teorici e istituzionali, Banca d'Italia.

Coase, R.H. (1937). "The Nature of the Firm". Economica, 4:386-485

Cornelli F. and Li D.D. (1994), "Large shareholders, private benefits of control and optimal schemes for privatisation", LSE Financial Markets Group, discussion paper series, n.185. 
Crémer, J. (1993), "Arms' length relationships", mimeo, IDEI, Tolosa.

De long, J. Breadford (1991), "Did Morgan's Men Add Value? An Economist Perspective on Financial Capitalism", in Peter Temin (ed.) Inside the Business Enterprise: Historical Perspectives on the Use of Information, Chicago: University Press.

Demsetz H. and Lehn K. (1985), "The structure of corporate ownership: causes and consequences", Journal of Political Economy, 93, 1155-77.

Edwards J. and Fisher K. (1991), "Banks, finance and investment in West Germany", CEPR discussion paper, n.497.

Edwards J. and Fisher K. (1994), "Banks, Finance and Investment in Germany", Cambridge, Cambridge University Press.

Franks J. and Mayer C. (1990), "Capital markets and corporate control: a study of France, Germany and the UK", Economic Policy, 11, pp. 191-231.

Fulghieri P. and Zingales L. (1994), "Privatizzazioni e struttura del controllo societario: il ruolo della public company", mimeo.

Grossman S. J. and Hart O. D. (1980), "Take-over bids, the free rider problem, and the theory of the corporation, Bell Journal of Economics, 11, pp.42-64.

Harris M. and Raviv A. (1988), "Corporate control contests and capital structure", Journal of Financial Economics, 20, pp.55-86.

Holmstrom and Tirole (1993), "Market Liquidity and Performance Monitoring", Journal of Political Economy, Vol. 101, no 4, 678-709

Jensen M. C. and Meckling W. H. (1976), "Theory of the firm: managerial behaviour, agency costs and ownership structure", Journal of Financial Economics, 11, pp.5-50.

Kaplan S. (1993a), "Top executive rewards and firm performance. A comparison of Japan and the U.S.". University of Chicago Working Paper.

Kaplan S. (1993b), "Top executives, management turnover and firm performance in Germany", University of Chicago Working Paper.

Kaplan, S and B. Minton (1993), "Outside Intervention in Japanese Companies: Its Determinants and Its Implications for Managers", NBER Working paper No.4276.

Lo Passo F., Macchiati A. (1995), "Gli assetti proprietari nella privatizzazione delle imprese di pubblica utilità", Rivista di Politica Economica, forthcoming.

McConnell J.J and Servaes H. (1990), "Additional evidence on equity ownership and corporate value", Journal of Financial Economics, 27, 595-612.

Miyajima H. (1994), "The privatisation of ex-zaibatsu holding stocks and the emergence of bank centered corporate groups in Japan", mimeo. 
Modigliani, F. and Miller M.H. (1958), "The cost of capital, corporate finance and the theory of investment", American Economic Review, 48, pp.261-297.

Mork R., Shleifer A. and Vishny R. (1988), "Management ownership and market valuation. An empirical analysis", Journal of Financial Economics, 20, pp. 293-315.

Nakatani I. (1984), "The role of financial corporate grouping", in : M. Aoki, ed.,Economic analisis of the Japanese firm (North Holland, New York).

Nicodano G. (1993), "The value of non-voting shares and pyramidal groups", Università L. Bocconi, Paolo Baffi Centre, Working Paper, n.77.

OECD (1989), "Disclosure of information by Multinational enterprises", working document by the Working Group on Accounting Standards, no. 6.

Prowse S. (1995), " Corporate governance in an international perspective: A survey of corporate control mechanisms among large firms in the U.S., U.K., Japan and Germany", Financial markets, institutions \& instruments, v.4 n.1.

Roe M. J. (1990), "Political and legal restraint on ownership and control of public companies", Journal of Financial Economics, 27, pp. 7-41.

Roe M. J. (1994), Strong managers, weak owners. The political roots of American corporate finance, Princeton, NJ: Princeton University Press.

Schleifer A.and Vishny R. W. (1986), "Large shareholders and corporate control", Journal of Political Economy, vol.94, no.3.

Sheard P. (1989), "The main bank system and corporate monitoring and control in Japan", Journal of Economic Behavior and Organisation, 11, pp. 399-422.

Shleifer A. and Vishny R.W. (1995), "A survey of corprate governance", mimeo.

Slovin M.B. and Sushka M.E. (1993), "Ownership concentration, corporate control activity, and firm value: evidence from the death of inside blockholders", Journal of Finance, XLVIII, n. 4, pp.1293-1321.

Stulz R. M (1988), "Management control of voting rights. Financing policies and the market for corporate control", Journal of Financial economics, 20, pp. 25-53.

Weinstein D.E. and Yafeh Y. (1994)," On the costs of a Bank Centered Financial System: evidence from the changing main bank relations in Japan", paper presented at the CEPR|ECARE Workshop, Brussels 28/29 October 1994.

Wruck K. H. (1989), "Equity ownership concentration and firm value", Journal of Financial Economics, 23, pp. 3-28. 